\title{
Genetic structure of island populations of the anurans Rana temporaria and Bufo bufo
}

\author{
PERTTU SEPPÄ*† \& ANSSI LAURILA $\$$ \\ $\dagger$ Division of Genetics, Department of Biosciences, and $\ddagger$ Division of Population Biology, Department of Ecology and \\ Systematics, University of Helsinki, Helsinki, Finland.
}

\begin{abstract}
Amphibians have traditionally been considered to have low dispersal ability and they have become a model for studies on the effects of man-made habitat fragmentation on genetic variation and population differentiation. This study examined the genetic population structure in the common frog (Rana temporaria) and the common toad (Bufo bufo) in an archipelago of the northern Baltic Sea. Heterozygosity was not correlated with distance of the island from the mainland nor, in $R$. temporaria, with effective population size based on census estimates. Generally, no inbreeding was detected in island populations. The overall differentiation among islands was weak, but the $F_{\mathrm{ST}}$ values were significantly larger in $R$. temporaria $\left(F_{\mathrm{ST}}=0.068\right)$ than in B. bufo $\left(F_{\mathrm{ST}}=0.019\right)$. Most of the differentiation was a result of differences among groups of islands, differentiation within them playing a minor role. Thus, assuming Wright's island model of migration, gene flow was rather high among closely located islands, but longer distances seemed to form a slight dispersal barrier for $R$. temporaria. Strong gene flow within the study area was confirmed by lack of isolation by distance. The estimated effective population sizes in $R$. temporaria were small, the average being 32 breeding females per island. The results indicate that gene flow between island populations across the matrix of open, brackish-water sea is extensive and suggest that the anurans are well able to disperse in this natural metapopulation system.
\end{abstract}

Keywords: anurans, Bufo, gene flow, isolation by distance, population size, Rana.

\section{Introduction}

In the face of man-made habitat fragmentation, studies of processes affecting genetic population structure in fragmented habitats are becoming increasingly important. Neutral genetic variation in such a subdivided system is regulated most importantly by two factors. First, gene flow between local populations tends to homogenize the genetic composition of the whole system so that genetic variation becomes equally distributed between subpopulations. As a result, there will be no differences between the subpopulations. Secondly, when gene flow is restricted, allele frequency differences may arise between local populations, and different levels of genetic variation may be found as a result of increased genetic drift (Avise, 1994).

Genetic differentiation among local populations can be measured using genetic markers. These measures can then be translated into a biologically more meaningful

\footnotetext{
*Correspondence and present address: Department of Genetics, Uppsala University, Box 7003, S-75007 Uppsala, Sweden.

E-mail: perttu.seppa@genetik.uu.se.
}

quantity, the amount of gene flow among populations, by using a demographic model. Wright's island model of migration (Wright, 1969) is most commonly used for this purpose. Although violations from its assumptions (equal gene flow from any local population to any other local population, equal size of local populations, etc.) may affect the level of gene flow among populations (Whitlock, 1992; Giles \& Goudet, 1997), it is clear that the distribution of genetic variation in the system is largely influenced by the organism's dispersal ability.

Among vertebrates, amphibians are relatively poor dispersers and highly philopatric (Blaustein et al., 1994). This makes them particularly vulnerable to degradation of the environment and to drastic changes in population size (Blaustein et al., 1994; Beebee, 1996). Consequently, amphibians have recently become a focus for studies on the effect of man-induced habitat fragmentation on genetic diversity and population differentiation (Reh \& Seitz, 1990; Hitchings \& Beebee, 1997, 1998). This paper reports the study of genetic population structure in a pristine population system comprising natural island populations of two anurans, the common frog (Rana temporaria) and the common toad (Bufo bufo). Both 
species have recently been shown to suffer from inbreeding and reduced fitness in urban areas (Reh \& Seitz, 1990; Hitchings \& Beebee, 1997, 1998), but data from pristine natural habitats are lacking.

An analysis was made of the genetic population structure of $R$. temporaria and $B$. bufo by using allozymes as markers. First, the amount of genetic variation within the island populations was described by calculating expected heterozygosities (gene diversity), and estimating inbreeding coefficients. Secondly, genetic differentiation was studied among local populations at different levels of isolation with Wright's traditional $F$ statistics analysis (Wright, 1969). Thirdly, isolation by distance was explored within the study area by using pairwise $F_{\mathrm{ST}}$ estimates associated with geographical distances between populations. Finally, the effective population sizes of the local populations of $R$. temporaria were estimated using census data on the number of egg clutches.

\section{Materials and methods}

\section{Study area and sampling}

Both B. bufo and $R$. temporaria are common and widespread in southern Finland, where they breed in late April-early May. Larvae metamorphose during the period from mid-June until mid-August. Tadpole samples were collected in late May-early June 1994 from islands and mainland near Tvärminne Zoological Station, Hanko, SW Finland. The Baltic Sea around the islands is brackish water (salinity $\approx 6 \%$ ). On the islands, the anurans reproduce in freshwater rock pools (Laurila, 1998), but both adults and juveniles can sometimes be found along the seashore (A. Laurila, pers. obs.).

All the rock pools in an area of about $30 \mathrm{~km}^{2}$ were thoroughly surveyed over the period of several years for spawn clumps and tadpoles (Laurila, 1998). Twenty-five islands were found to be inhabited by $R$. temporaria, and tadpoles were sampled from 12 of these and from two mainland sites (Table 1, Fig. 1). The unsampled islands had only a very small number of breeding individuals (harmonic mean of breeding females close to 1.0 ), or they were very close (less than $100 \mathrm{~m}$ ) to other, more densely populated islands. Bufo bufo was found on only six islands, which were all sampled (Table 1, Fig. 1). The sampled islands formed five groups. The distances between the islands within each group ranged from 0.2 to $2.5 \mathrm{~km}$ (average $1.0 \mathrm{~km}$ ), and between the groups of islands from 1.4 to $7.5 \mathrm{~km}$ (average $3.9 \mathrm{~km}$ ).

The samples were collected by sweep-netting from rock pools where the numbers of reproducing females were highest. Whenever possible, several pools on each island were sampled, and the samples from different pools were combined. To avoid possible effects of kinbiased schooling behaviour (Waldman \& Alder, 1979) on sampling, larvae were collected from several locations in each pool.

\section{Electrophoresis}

The samples were analysed by standard horizontal electrophoresis using starch gels. Twenty-three enzyme systems were screened in both species, with 13 loci in $R$. temporaria and 11 in B. bufo giving reliable results.

Table 1 Study populations of Rana temporaria and Bufo bufo. Sample sizes (in parentheses, the number of individuals studied for the polymorphic loci) and expected heterozygosities across loci $\left(H_{\mathrm{e}}\right)$ are shown. The two mainland populations are Landbjörkskär (3.3) and Tvärminneö (5.1)

\begin{tabular}{lc}
\hline Location & $H_{\mathrm{e}}$ \\
\hline R. temporaria & \\
Furuskär group & \\
1.1 Furuskär (48) & 0.142 \\
1.2 Långskär (45) & 0.165 \\
1.3 Lillhamn (44) & 0.177 \\
1.4 Brännskär (46) & 0.150 \\
1.5 Mellanskär (40) & 0.127 \\
Porskär group & \\
2.1 Porskär (49) & 0.142 \\
2.2 Västra Hamnskär (40) & 0.208 \\
2.3 Norra Porskär (40) & 0.138 \\
2.4 Vargskär (43) & 0.188 \\
Vindskär group & \\
3.1 Vindskär (56) & 0.135 \\
3.2 Isskär (33) & 0.138 \\
3.3 Landbjörkskär (30) & 0.119 \\
Spikarna group & \\
4.1 Spikarna (37) & 0.154 \\
Tvärminne group & \\
5.1 Tvärminneö (30) & \\
B. bufo & 0.165 \\
Furuskär group & \\
1.1 Furuskär (80) & \\
1.2 Långskär (65) & \\
1.3 Lillhamn (73) & \\
Porskär group & \\
2.1 Porskär (110) & 0.091 \\
Vindskär group & 0.084 \\
3.1 Vindskär (72) & 0.085 \\
3.2 Isskär (82) & \\
\hline & 0.089 \\
\hline
\end{tabular}

(C) The Genetical Society of Great Britain, Heredity, 82, 309-317. 
Fig. 1 Location of the study populations in the Tvärminne archipelago in SW Finland. Table 1 lists the codes for the islands, and Table 4 gives details of the population sizes.

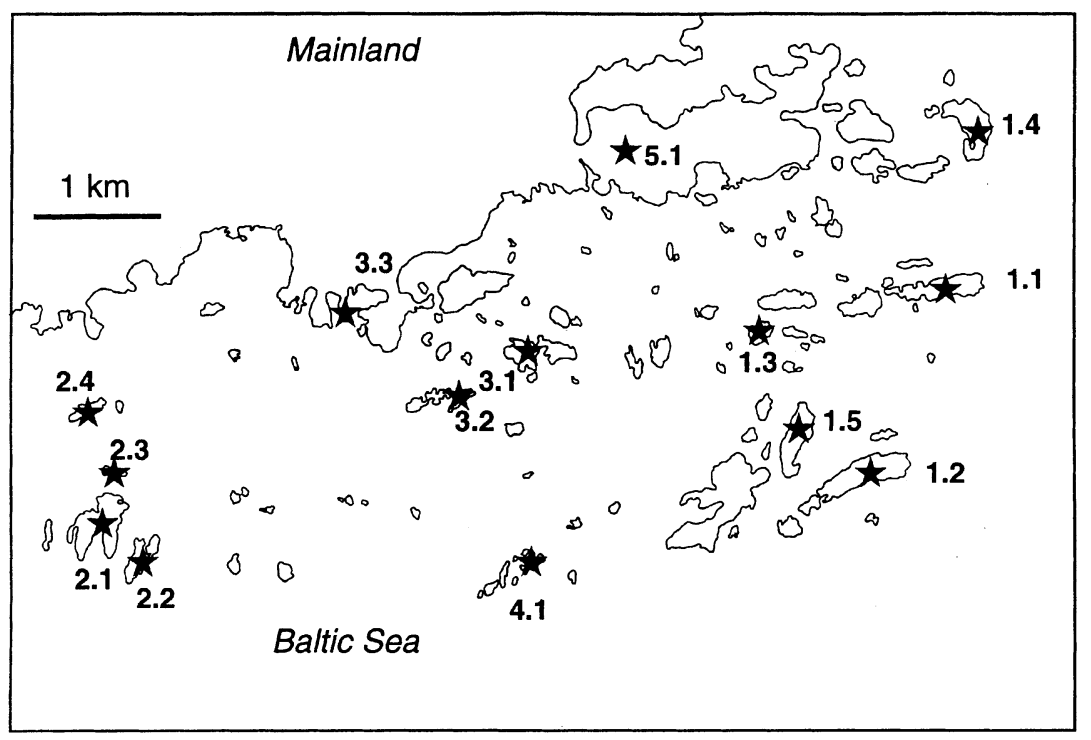

Initially, about 20 individuals from each population were analysed to determine the amount of variation at these loci. For the loci regarded as monomorphic after screening, rare alleles could have been missed because of sampling error, but the frequency of such alleles would have been only $2-3 \%$.

More samples were analysed for the loci that turned out to be polymorphic. The final average sample sizes were 42 and 80 for R. temporaria and B. bufo, and the total number of animals studied was 581 and 482, respectively. The following five loci were polymorphic in R. temporaria: isocitrate dehydrogenase (EC 1.1.1.42, IDH), phosphogluconate dehydrogenase (EC 1.1.1.44, PGD), phosphoglycerate kinase (EC 2.7.2.3, PGK), aconitase (EC 4.2.1.3, ACO) and mannose-6-phosphate isomerase (EC 5.3.1.8, MPI). In B. bufo two loci were polymorphic: malic enzyme (EC 1.1.1.40, ME) and IDH. More details of the electrophoretic conditions are given in Laurila \& Seppä (1998).

\section{Genetic population structure}

The amount of genetic variation in the populations is described by calculating average expected heterozygosity (gene diversity, $H_{\mathrm{E}}$ ). Deviation from panmixia was also analysed by using exact tests (Rousset \& Raymond, 1995). Wright's $F$-statistics were used to describe genetic differentiation among the island populations. The standardized allele frequency variance among populations $\left(F_{\mathrm{ST}}\right)$ describes the amount of genetic differentiation between subpopulations. The other indices are the inbreeding coefficients of the subpopulations and the whole population ( $F_{\text {IS }}$ and $F_{\text {IT }}$, respectively; Wright, 1951). Because of the hierarchical structure of the present study, genetic variation was divided into three levels: among all islands, among groups of islands, and among nearby islands within the groups. First the $F$-indices $\left(F_{\mathrm{ST}}, F_{\mathrm{IS}}, F_{\mathrm{IT}}\right)$ were estimated regarding all islands as separate. Then the data sets from the nearby islands were pooled, and differentiation among groups of islands $\left(F_{\mathrm{GT}}\right)$ was estimated. Finally, the last $F_{\mathrm{ST}}$ component describing genetic differentiation among the nearby islands $\left(F_{\mathrm{SG}}\right)$ was obtained by solving eqn (1) (Nei, 1977) for $F_{\mathrm{SG}}$, and substituting the estimates above:

$$
1 \quad F_{\mathrm{IT}}=\left(1 \quad F_{\mathrm{IS}}\right)\left(1 \quad F_{\mathrm{SG}}\right)\left(1 \quad F_{\mathrm{GT}}\right) .
$$

$F$-indices $\left(F_{\mathrm{ST}}, F_{\mathrm{IS}}, F_{\mathrm{IT}}, F_{\mathrm{GT}}\right)$ were estimated following Cockerham $(1969,1973)$. Geographical structuring of the data was also explored by calculating pairwise $F_{\mathrm{ST}^{-}}$ values between all pairs of populations, and by plotting these against the metric distances of the corresponding pairs (Rousset, 1997). The isolation by distance was tested using a Mantel test (Mantel, 1967). The $F$-analysis was made using software DIPLOID.FOR (Weir, 1990), which jackknifes the estimates over populations and loci to obtain standard errors. All other calculations were made by using GENEPOP (Raymond \& Rousset, 1995).

According to Wright's island model of migration, genetic differentiation among subpopulations at an equilibrium of gene flow and genetic drift is a function of the population size $\left(N_{\mathrm{e}}\right)$ and migration rate $(\mathrm{m})$ (Wright, 1969):

$F_{\mathrm{ST}} \cong 1 /\left(1+4 N_{e} m\right)$.

The product $N_{\mathrm{e}} m$ refers to the actual number of migrating individuals per generation needed to maintain 
the level of differentiation measured. Because $F_{\mathrm{ST}}$ could be estimated from the genetic data, $N_{\mathrm{e}} m$ could be obtained at different levels of isolation. Furthermore, as the effective population sizes were available for $R$. temporaria, migration rates could also be calculated.

\section{Effective population size}

An estimate of the effective sizes of $R$. temporaria populations was obtained by censusing egg clutches in all rock pools in the islands each spring during 1993-97. Rana temporaria females lay only a single clutch of eggs per year (Savage, 1961), and the number of egg clutches represents the number of breeding females in the population (Laurila, 1998). The three last censuses were made after sampling for the genetic analysis, but as they made no difference to the other counts they were also included. The effective number of breeding females of each population was calculated based on these censuses as a harmonic mean of the censused population sizes across five succeeding years (Avise, 1994).

\section{Results}

\section{Genetic variation and inbreeding}

Allele frequencies of the polymorphic loci are shown in the appendix. The average expected heterozygosities were roughly twice as high in $R$. temporaria as in $B$. bufo (Table 1). There was no relationship between heterozygosity and the isolation of the population (measured as the distance of the island to mainland; linear regression: $R$. temporaria, d.f. $=13, b=0.02 ; r^{2}=0.04 ; B$. bufo: d.f. $=5, b=0.01 ; r^{2}=0.01$; both NS). Furthermore, there was no relationship between heterozygosity and $(\log )$ population sizes in $R$. temporaria (d.f. $=13$, $b=0.04 ; r^{2}=0.09$, NS).

Results from the present study do not show any consistent indication of inbreeding. In the combined data, all but one locus were in Hardy-Weinberg equilibrium with inbreeding coefficients equalling zero $\left(F_{\text {IS }}>0\right.$, all NS; $F_{\text {IS }}<0$, all NS). The only exception was $P g k$ in $R$. temporaria, where the inbreeding coefficient was significantly larger than zero $(P<0.001)$. Consequently, the overall average inbreeding estimates within subpopulations were low, and insignificant in both species (based on the standard errors; two-tailed $t$ tests: $R$. temporaria: $t_{13}=0.97 ;$ B. bufo: $t_{5}=0.11$; both NS). Most single populations were in HardyWeinberg equilibrium, too. In $R$. temporaria, two populations had an excess $(F<0$ : Furuskär: $P=0.039$; Landbjörkskär: $P=0.033$ ) and three populations a deficiency of heterozygotes $(F>0$ : Lillhamn: $P=$ 0.002; Brännskär: $P<0.001$; Vindskär: $P=0.042$ ).

\section{Genetic population structure}

There was no strong genetic differentiation among island populations at the geographical scale of this study. In $R$. temporaria, differentiation among all islands was moderate $\left(F_{\mathrm{ST}}=0.068 \pm 0.014\right)$, and the major part of this differentiation $(68 \%)$ was attributable to differentiation among the groups of islands $\left(F_{\mathrm{GT}}=0.046 \pm 0.017\right)$. The $F_{\mathrm{ST}}$ and $F_{\mathrm{GT}}$ estimates were both significantly larger than zero (one-tailed $t$-tests, both $P<0.02$ ). Allele frequency variation within groups of islands played a minor role $\left(F_{\mathrm{SG}}=0.024\right)$. It is shown below that the mainland populations of $R$. temporaria [Landbjörkskär (3.3) and Tvärminneö (5.1)] may be the source of a large proportion of allele frequency variance detected by the $F$-analysis, and that these populations may not fulfil the requirements of the island model. Therefore the $F$ analysis was recalculated, excluding these two populations, to estimate gene flow among the islands. The $F_{\mathrm{ST}}$ values dropped somewhat $\left(F_{\mathrm{ST}}=0.054 \pm 0.009\right.$, $\left.F_{\mathrm{GT}}=0.029 \pm 0.008\right)$, but both estimates remained significantly larger than zero (one-tailed $t$-tests, both $P<0.01$ ). Differentiation among nearby islands within groups of islands remained practically the same $\left(F_{\mathrm{SG}}=0.026\right)$.

In $B$. bufo, the allele frequency variance was generally lower than in R. temporaria (Table 2). Differentiation among all islands was only slight $\left(F_{\mathrm{ST}}=0.019 \pm 0.003\right)$, although the estimate was significantly larger than zero (one-tailed $t_{5}=6.33$, $P<0.001)$. The estimate was also significantly smaller than in $R$. temporaria (two-tailed $t_{18}=50.3$, $P<0.001)$. Differentiation among groups of islands $\left(F_{\mathrm{GT}}=0.016 \pm 0.013\right)$ was almost identical to that among all islands, but not significantly larger than zero (one-tailed $t_{2}=1.23, P=0.172$ ). Consequently, most of the differentiation was again attributable to differences among groups of islands (84\%), and there was practically no differentiation within groups of islands $\left(F_{\mathrm{SG}}=0.003\right)$.

\section{Effective population size and gene flow}

Assuming an island model of migration, the estimates of the numbers of migrating individuals $\left(N_{\mathrm{e}} m\right.$, Table 3$)$ are straightforwardly connected to the $F_{\mathrm{ST}}$ estimates by eqn (2). In both species, gene flow was high, although more pronounced in B. bufo. In $R$. temporaria, the $F_{\mathrm{ST}}$ estimates (excluding populations 3.3 and 5.1) give $N_{\mathrm{e}} m$ values between 3.6 and 8.6 as the average numbers of migrants per generation. In B. bufo, $F_{\mathrm{ST}}$ estimates translate into 12.9 and 15.4 migrants per generation between all islands and groups of islands, respectively. 
Table $2 F$-statistics. $F_{\text {IS }}$ and $F_{\text {IT }}$ are inbreeding coefficients in the separate islands and in the whole population, respectively. $F_{\mathrm{ST}}$ refers to the allele frequency variance among all islands, $F_{\mathrm{GT}}$ to that among groups of islands, and $F_{\mathrm{SG}}$ to that among islands within the groups of islands. Note that $F_{\mathrm{SG}}$ was obtained by solving eqn (1) for $F_{\mathrm{SG}}$

\begin{tabular}{lcc}
\hline & Rana temporaria & Bufo bufo \\
\hline$F_{\mathrm{IS}}$ & $0.060 \pm 0.062$ & $0.012 \pm 0.057$ \\
$F_{\mathrm{IT}}$ & $0.125 \pm 0.067$ & $0.007 \pm 0.061$ \\
$F_{\mathrm{ST}}$ & $0.068 \pm 0.014$ & $0.019 \pm 0.003$ \\
$F_{\mathrm{GT}}$ & $0.046 \pm 0.017$ & $0.016 \pm 0.013$ \\
$F_{\mathrm{SG}}$ & 0.024 & 0.003 \\
\hline
\end{tabular}

The low $F_{\mathrm{ST}}$ value within the groups $\left(F_{\mathrm{SG}}=0.003\right)$ gives a very high number of migrants $\left(N_{\mathrm{e}} m=83.1\right)$.

The sizes of $R$. temporaria populations were highly variable, both spatially and temporally, ranging from one to 363 breeding females (Table 4). The effective population sizes estimated over 5 years ranged from fewer than two females in Mellanskär to 164 in Porskär (Table 4). The average effective population size was 31.7 breeding females, and 34.8 females excluding populations 3.3 and 5.1. If the latter figure is multiplied by two to obtain an effective population size that includes both sexes (assuming equal sex ratio), migration rate $(m)$ can be extracted from the number of migrating individuals $\left(N_{\mathrm{e}} m\right.$, Table 3$)$. This gives $5-12 \%$ in every generation as the average proportion of migrants in the island populations. Furthermore, the estimate of the effective population size was only crude and likely to be an overestimate, because any variance in male reproductive success would cause it to decrease. A decreasing population size would straightforwardly increase the proportion of the migrants.

Table 3 Estimates of genetic differentiation $\left(F_{\mathrm{XX}}\right)$, and corresponding numbers of migrating individuals $\left(N_{\mathrm{e}} m\right)$ at different levels of isolation in the island populations of Rana temporaria and Bufo bufo. In R. temporaria, F-indices were calculated excluding mainland populations 3.3 and 5.1. Mean effective population size $\left(N_{\mathrm{e}}\right)$ and migration rates ( $m$ ) are also shown for $R$. temporaria. Different $F$-indices are explained in Table 3

\begin{tabular}{lcccc}
\hline & $F$ & $N_{\mathrm{e}} m$ & $N_{\mathrm{e}}$ & $m$ \\
\hline R. temporaria & & & & \\
$F_{\mathrm{ST}}$ & 0.054 & 3.6 & 69.5 & 0.052 \\
$F_{\mathrm{GT}}$ & 0.029 & 7.6 & & 0.109 \\
$F_{\mathrm{SG}}$ & 0.026 & 8.6 & & 0.124 \\
B. bufo & & & & \\
$F_{\mathrm{ST}}$ & 0.019 & 12.9 & & \\
$F_{\mathrm{GT}}$ & 0.016 & 15.4 & & \\
$F_{\mathrm{SG}}$ & 0.003 & 83.1 & & \\
\hline
\end{tabular}

The pairwise $F_{\mathrm{ST}}$ estimates plotted against the metric distances between the population pairs did not reveal any clear geographical structuring in the data (Fig. 2). There was no correlation between the genetic and metric distance among the pairs of populations in either species (R. temporaria: $n=14, r_{\mathrm{s}}=-0.080 ;$ B. bufo: $n=6$, $r_{\mathrm{s}}=0.027$; Mantel tests NS in both species). An interesting pattern emerges from the results on $R$. temporaria, however. When either Landbjörkskär (3.3) or Tvärminneö (5.1) was a member of the pair, the pairwise $F_{\mathrm{ST}}$ estimates were relatively high. Of the pairwise $F_{\mathrm{ST}}$ with Landbjörkskär or Tvärminneö, $79 \%$ and $62 \%$, respectively, were in the upper quartile of the distribution of the estimates.

\section{Discussion}

\section{Genetic variation in the island populations}

The amount of genetic variation in the island populations of $R$. temporaria and B. bufo was generally low. All the polymorphic loci had only two or three alleles, which is much fewer than found previously; for example, Hitchings \& Beebee (1997) and Reh \& Seitz (1990) found 15 and 10 alleles at $M p i$, respectively, whereas the corresponding figure in the present study was three. Low levels of genetic variation can be expected based on small population sizes in the islands. Yet the study population and sample sizes were comparable to those in the studies cited. Alternatively, low levels of genetic variation may be expected in northern fringe populations (Sjögren, 1991; Merilä et al., 1996), which may also result from small population sizes. However, the northern distribution boundaries are more than 1200 and $800 \mathrm{~km}$ north of the present study areas for R. temporaria and B. bufo, respectively (Gasc et al., 1997).

Expected heterozygosities in single populations were not correlated with the effective population sizes estimated by censusing egg masses, nor with the crude isolation indices we devised. The isolation distance and population size may be of minor importance, however, if strong gene flow homogenizes the genetic composition of the whole population. The long-term effective population sizes, for instance, may have been even smaller than estimated here because of bottlenecking, but, given enough time, gene flow may have resulted in an even distribution of allele frequencies. Thus gene flow has probably equalized the amount of genetic variation in the population and the differences found across the islands may therefore simply represent sampling variance.

No indication of inbreeding was found in either species in the present study. Most individual populations were at Hardy-Weinberg equilibrium, although in 
Table 4 Population sizes in Rana temporaria as numbers of breeding females. $N_{\mathrm{e}}$ is the effective population size for females (calculated as harmonic mean across five years). The arithmetic mean is calculated both for all populations and for the 12 populations considered to fulfil the assumptions of Wright's island model

\begin{tabular}{|c|c|c|c|c|c|c|}
\hline Population no. $\dagger$ & 1993 & 1994 & 1995 & 1996 & 1997 & $N_{\mathrm{e}}$ \\
\hline 1.1 & 16 & 16 & 3 & 5 & 8 & 6.4 \\
\hline 1.2 & 86 & 121 & 73 & 75 & 104 & 88.4 \\
\hline 1.3 & 9 & 31 & 5 & 14 & 7 & 9.0 \\
\hline 1.4 & 13 & 21 & 15 & 19 & 30 & 18.0 \\
\hline 1.5 & 4 & 6 & 2 & 1 & 1 & 1.7 \\
\hline 2.1 & 119 & 182 & 99 & 269 & 363 & 164.1 \\
\hline 2.2 & 36 & 52 & 32 & 38 & 44 & 39.3 \\
\hline 2.3 & 20 & 11 & 10 & 15 & 7 & 11.1 \\
\hline 2.4 & 21 & 34 & 50 & 35 & 23 & 29.6 \\
\hline 3.1 & 15 & 98 & 43 & 88 & 109 & 41.4 \\
\hline 3.2 & 1 & 10 & 5 & 22 & 10 & 3.5 \\
\hline 3.3 & & 50 & 10 & & & 16.7 \\
\hline 4.1 & 9 & 18 & 7 & 4 & 2 & 4.7 \\
\hline 5.1 & & 10 & 10 & & & 10.0 \\
\hline Arithmetic mean & & & & & & 31.7 \\
\hline Arithmetic mean/12 pop. & & & & & & 34.8 \\
\hline
\end{tabular}

†See Table 1.

$R$. temporaria exceptions were found in both directions. The average inbreeding coefficient $\left(F_{\text {IS }}\right)$ also equalled zero in both species. $F_{\text {IS }}$ either refers to true inbreeding within subpopulations or to further genetic substructuring within these areas (Wahlund effect). Although both species breed in several rock pools on the islands (Laurila, 1998), mating appears to be random within the islands (Laurila \& Seppä, 1998) rendering genetic substructuring within island populations an unlikely explanation.

\section{Genetic differentiation among the island populations}

$F_{\mathrm{ST}}$ values exceeding 0.2 show important genetic differentiation among populations (Avise, 1994). In this study, genetic differentiation was expected because low mobility and high site fidelity are general features of amphibians (Blaustein et al., 1994; Beebee, 1996). However, differentiation among $R$. temporaria and B. bufo island populations was generally weak, although significant in both species. The results obtained by the present study suggest that gene flow is only little restricted at the scale of this study area, although there was an indication that longer distances may somewhat constrain gene flow in $R$. temporaria. In $B$. bufo, on the other hand, the extremely low $F_{\mathrm{ST}}$ estimate showed free gene flow among closely located islands, and also ample gene flow across larger distances. Adult philopatry is suggested to be high in these species (Blab, 1986; Reading et al., 1991). If this is true, juvenile dispersal must be an important mechanism damping genetic differentiation between the populations (Beebee, 1996). The documented migratory range of anuran juveniles in terrestrial habitats covers $2-5 \mathrm{~km}$ (e.g. Dole, 1971; Reading et al., 1991), but the maximum range may be considerably larger. As many amphibians are able to tolerate brackish water for long periods (Ruibal, 1959), the northern Baltic sea is probably not as strong a dispersal barrier for these species as a matrix of marine water would be.

An alternative explanation for the low genetic differentiation within the study area is that the anurans have only recently colonized the area, and there may not have been enough time for the genetic differences among island populations to emerge as a result of drift. This seems unlikely, however, because old maps show that suitable habitats have existed for several hundreds of years on the islands and there is no reason to assume that the anurans have not been present during that time. In fact, several recent studies have shown that young populations may be relatively highly differentiated as a result of colonization/extinction processes (Whitlock, 1992; Giles \& Goudet, 1997).

The two species varied somewhat in their differentiation patterns. Differentiation in $R$. temporaria was significantly stronger than in $B$. bufo, despite the fact that $B$. bufo had, on average, longer distances between populations than $R$. temporaria (Fig. 1). This suggests that $B$. bufo is a better disperser than $R$. temporaria. This superior dispersal ability of $B$. bufo may be caused by the difference in palatability between the species. 
Fig. $2 F_{\text {ST }}$ estimates of all pairs of (a) 14 Rana temporaria and (b) six Bufo bufo populations plotted against their geographical distances. In $R$. temporaria, filled circles represent pairs where one of the mainland populations [Landbjörkskär (3.3) or Tvärminneö (5.1)] was the other member of the pair.
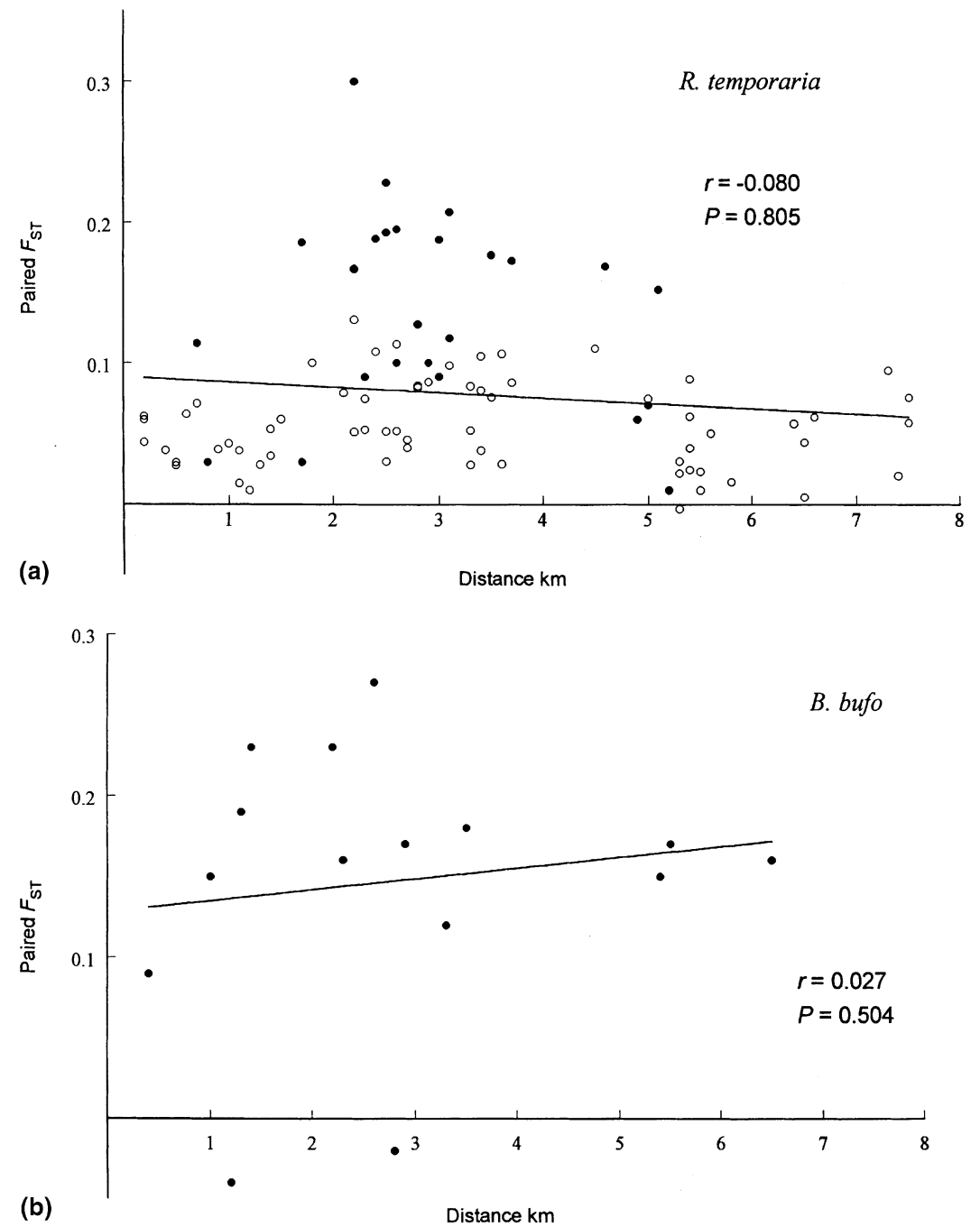

Bufo bufo have noxious skin compounds which effectively make them unpalatable to various predators including fish (Duellman \& Trueb, 1986; Laurila, 1998). Rana temporaria lacks such defences. As an amphibian swimming in the open sea is easy prey for a predator, chemical defence may enable greater dispersal success of $B$. bufo between islands. If mortality during dispersal is higher in $R$. temporaria, more pronounced differentiation would be expected in this species. This hypothesis is supported by casual observations of individual B. bufo swimming in the open sea of the northern Baltic, and by $R$. temporaria occasionally occurring in the diet of large gulls (Kilpi \& Byholm, 1995; M. Kilpi, pers. comm.).

More detailed analysis of the amount of gene flow generally confirmed the pattern emerging from the $F$ analysis. Because the number of migrants $\left(N_{\mathrm{e}} m\right)$ directly depends on the $F_{\mathrm{ST}}$ estimated, there were more migrants in $B$. bufo than in $R$. temporaria. Depending on the level of isolation, an average of four to nine individuals migrate every generation in $R$. temporaria, whereas in $B$. bufo the corresponding figures range from 13 to 83 individuals. With the effective population sizes estimated here, an average of up to $12 \%$ of the $R$. temporaria breeding populations in the islands are migrants in each generation, which again is an indication of strong dispersal and gene flow.

No direct estimates were made of the size of the B. bufo populations in the present study area, but they typically appear to be smaller than in $R$. temporaria in the same islands (A. Laurila, pers. obs.). Therefore, assuming population sizes similar to those in $R$. temporaria on these islands, the migration rate in $B$. bufo would be about $15 \%$ over longer distances, whereas within nearby islands, the majority $(80 \%)$ of breeding individuals would be migrants. Because these are minimum estimates, gene flow in $B$. bufo does not seem to be at all restricted at this geographical scale.

Despite the indication that gene flow may be somewhat constrained over longer distances in $R$. temporaria,

(C) The Genetical Society of Great Britain, Heredity, 82, 309-317. 
no systematic isolation by distance effect was found when plotting pairwise $F_{\mathrm{ST}} \mathrm{S}$ against the geographical distances. The only exceptions were the Landbjörkskär and Tvärminneö populations. Both of these were located on the mainland and showed a slight but consistent sign of being genetically different from the island populations. This may be explained by easier dispersal and gene flow from other mainland sources to these populations than to island populations, and vice versa. Thus, these populations seem to fulfil the assumptions of Wright's island model poorly.

\section{Naturally and unnaturally subdivided anuran populations}

Rana temporaria and $B$. bufo have recently been studied in a system where local populations were isolated because of road construction and other forms of urban development (Reh \& Seitz, 1990; Hitchings \& Beebee, 1997, 1998). Even though the size of the study areas and the local population sizes in these studies were comparable to that presented here, their results on genetic population structure were profoundly different. Both significant inbreeding (Reh \& Seitz, 1990; Hitchings \& Beebee, 1997) and strong genetic differentiation among local populations (Reh \& Seitz, 1990; Hitchings \& Beebee, 1997, 1998) were found. The authors suggested that population differentiation resulted from urban development restricting gene flow and causing subsequent inbreeding as a result of population decline and isolation.

Differentiation among island populations in the present natural study system was only weak, and no signs of inbreeding were found, even though the effective population sizes were extremely small in some of the islands. Thus, the matrix of open brackish-water sea is much less effective in restricting gene flow than dispersal barriers caused by urban development. It seems that $R$. temporaria and B. bufo are well able to disperse over moderate distances between habitat patches as long as unnatural dispersal barriers are not introduced. However, further studies in natural amphibian populations are needed to assess the amount of gene flow at a larger geographical scale.

\section{Acknowledgements}

Tvärminne Zoological Station provided the working facilities during the sampling. We thank Trevor Beebee, Martin Lascoux, Juha Merilä, Nina Peuhkuri, Lotta Sundström and an anonymous reviewer for constructive comments on the manuscript. This work was supported by the University of Helsinki (to P.S., A.L.), the Academy of Finland (P.S., A.L.), Emil Aaltonen Foundation (P.S.) and NorFA (A.L.).

\section{References}

AVISE, J. 1994. Molecular Markers, Natural History and Evolution. Chapman \& Hall, New York.

BEEBEE, T. J. C. 1996. Ecology and Conservation of Amphibians. Chapman \& Hall, London.

BLAB, J. 1986. Biologie, Ökologie und Schutz von Amphibien. Kilda-Verlag, Bonn.

BLAUSTEIN, A. R., WAKE, D. B. AND SOUSA, W. P. 1994. Amphibian declines: Judging stability, persistence, and susceptibility of populations to local and global extinctions. Conserv. Biol., 8 , 60-71.

COCKerham, C. C. 1969. Variance of gene frequencies. Evolution, 23, 72-84.

COCKerham, C. c. 1973. Analyses of gene frequencies. Genetics, 74, 679-700.

DOLE, J. W. 1971. Dispersal of recently metamorphosed leopard frogs, Rana pipiens. Copeia, 1971, 221-228.

Duellman, w. E. AND TRueB, L. 1986. Biology of Amphibians. The John Hopkins University Press, Baltimore.

GASC, J.-P., CABELA, A., CRNOBRNJA-ISAILOVIC, J., DOLMEN, D., GROSSENBACHER, K., HAFFNER, P. ET AL. 1997. Atlas of Amphibians and Reptiles in Europe. Societas Europaea Herpetologica \& Muséum National d'Histoire Naturelle (IEGB/SPN), Paris.

GILES, B. E. AND GOUdET, J. 1997. Genetic differentiation in Silene dioica metapopulations: estimation of spatiotemporal effects in a successional plant. Am. Nat., 149, 507-526.

HITCHINGS, S.P. AND BEEBEE, T. J.C. 1997. Genetic substructuring as a result of barriers to gene flow in urban Rana temporaria (common frog) populations: implications for biodiversity conservation. Heredity, 79, 117-127.

HITCHINGS, S. P. AND BEEBEE, T. J. C. 1998. Loss of genetic diversity and fitness in Common Toad (Bufo bufo) populations isolated by inimical habitat. J. Evol. Biol., 11, 269-283.

KILPI, M. AND BYHOLM, P. 1995. Diet of courtship feeding herring gulls in the Gulf of Finland. Ornis Fenn., 72, 135137.

LAURILA, A. 1998. Breeding habitat selection and larval performance of two anurans in freshwater rock-pools. Ecography, 21, 484-494.

LAURILA, A. AND SEPPÄ, P. 1998. Multiple paternity in the common frog (Rana temporaria): genetic evidence from tadpole kin groups. Biol. J. Linn. Soc., 63, 221-232.

MANTEL, N. 1967. The detection of disease clustering and a generalized regression approach. Cancer Res., 27, 209-220.

MERILÄ, J., BJÖRKLUND, M. AND BAKER, A. J. 1996. Genetic population structure and gradual northward decline of genetic variability in the greenfinch (Carduelis chloris). Evolution, 50, 2548-2557.

NEI, M. 1977. F-statistics and analysis of gene diversity in subdivided populations. Ann. hum. Genet., 41, 225-233.

RAYMOND, M. AND ROUSSET, F. 1995. GENEPOP (Version 1.2): population genetics software for exact tests and ecumenism. J. Hered., 86, 248-249.

READING, C. J., LOMAN, J. AND MADSEN, T. 1991. Breeding pond fidelity in common toads, Bufo bufo. J. Zool. Lond., 225, 201-211. 
REH, W. AND SEITZ, A. 1990. The influence of land use on the genetic structure of populations of the common frog Rana temporaria. Biol. Conserv., 54, 239-249.

ROUSSET, F. 1997. Genetic differentiation and estimation of gene flow from $F$-statistics under isolation by distance. Genetics, 145, 1219-1228.

ROUSSET, F. AND RAYMOND, M. 1995. Testing heterozygote excess and deficiency. Genetics, 140, 1413-1419.

RUIBAL, R. 1959. The ecology of a brackish water population of Rana pipiens. Copeia, 1959, 315-322.

SAVAGE, R. M. 1961. The Ecology and Life History of the Common Frog. Sir Isaac Pitman and Sons, London.

SJÖGREN, P. 1991. Genetic variation in relation to demography of peripheral pool frog populations (Rana lessonae). Evol. Ecol., 5, 248-271.
WALDMAN, B. AND ALDER, K. 1979. Toad tadpoles associate preferentially with siblings. Nature, 282, 611-613.

WEIR, B. S. 1990. Intraspecific differentiation. In: Hillis, D. M. and Moritz, C. (eds) Molecular Systematics, pp. 373-410. Sinauer Associates, Sunderland, MA.

WHITLOCK, M. C. 1992. Nonequilibrium population structure in forked fungus beetles: extinction, colonization, and the genetic variance among populations. Am. Nat., 139, 952970 .

Wright, s. 1951. The genetical structure of populations. Ann. Eugen., 15, 323-354.

WRIGHT, S. 1969. Evolution and the Genetics of Populations, vol. 2, the Theory of Gene Frequencies. The University of Chicago Press, Chicago.

\section{Appendix}

Allele frequencies in the study populations. For all loci, the most common allele is designated 100, and the other alleles either $F$ (fast) or $S$ (slow) according to their mobilities relative to the most common allele

\begin{tabular}{|c|c|c|c|c|c|c|c|c|c|c|c|c|c|c|c|}
\hline Population & \multicolumn{2}{|c|}{$M e$} & \multicolumn{3}{|c|}{$I d h$} & \multicolumn{2}{|c|}{$P g d$} & \multicolumn{3}{|c|}{$P g k$} & \multicolumn{2}{|c|}{ Aco } & \multicolumn{3}{|c|}{$M p i$} \\
\hline 1.1 & & & 0.672 & 0.078 & 0.250 & 0.917 & 0.083 & 0.813 & - & 0.188 & 0.667 & 0.333 & 0.585 & 0.415 & - \\
\hline 1.2 & & & 0.571 & 0.179 & 0.250 & 0.933 & 0.067 & 0.688 & 0.313 & - & 0.636 & 0.364 & 0.544 & 0.367 & 0.089 \\
\hline 1.3 & & & 0.438 & 0.063 & 0.500 & 0.875 & 0.125 & 0.619 & 0.286 & 0.095 & 0.583 & 0.417 & 0.591 & 0.398 & 0.011 \\
\hline 2.1 & & & 0.643 & 0.143 & 0.214 & 0.969 & 0.031 & 0.725 & 0.150 & 0.125 & 0.756 & 0.244 & 0.673 & 0.327 & - \\
\hline 2.2 & & & 0.400 & 0.167 & 0.433 & 0.921 & 0.079 & - & - & - & 0.756 & 0.244 & 0.375 & 0.525 & 0.100 \\
\hline 2.3 & & & 0.431 & 0.017 & 0.552 & 1 & - & 0.738 & 0.262 & - & 0.663 & 0.338 & 0.613 & 0.387 & - \\
\hline 2.4 & & & 0.448 & 0.103 & 0.448 & 0.769 & 0.231 & 0.684 & 0.316 & - & 0.570 & 0.430 & 0.425 & 0.500 & 0.075 \\
\hline 3.1 & & & 0.463 & 0.073 & 0.463 & 1 & - & 0.846 & 0.077 & 0.077 & 0.545 & 0.455 & 0.755 & 0.182 & 0.064 \\
\hline \multicolumn{16}{|l|}{ Bufo bufo } \\
\hline 1.1 & 0.509 & 0.491 & 0.438 & 0.563 & & & & & & & & & & & \\
\hline 1.2 & 0.684 & 0.316 & 0.400 & 0.600 & & & & & & & & & & & \\
\hline 1.3 & 0.659 & 0.341 & 0.459 & 0.541 & & & & & & & & & & & \\
\hline 2.1 & 0.561 & 0.439 & 0.550 & 0.450 & & & & & & & & & & & \\
\hline 3.1 & 0.708 & 0.292 & 0.625 & 0.375 & & & & & & & & & & & \\
\hline 3.2 & 0.640 & 0.360 & 0.561 & 0.439 & & & & & & & & & & & \\
\hline
\end{tabular}

(C) The Genetical Society of Great Britain, Heredity, 82, 309-317. 